\title{
The Analysis of Eighth Grader's Mathematical Literacy Ability in Solving HOTS Questions at SMPN 3 Tarakan
}

\author{
Setia Widia Rahayu ${ }^{1}$ \\ ${ }^{1}$ Mathemathics Education Department, Universitas Borneo Tarakan, Tarakan, Indonesia \\ Corresponding Author*Email: setiayura09@gmail.com
}

\begin{abstract}
This research is a qualitative descriptive study that aims to describe students' mathematical literacy skills of class VIII SMPN 3 Tarakan in solving HOTS questions. The subject in this study was a class VII student. This study used a test instrument which was the HOTS problem, semi-structured interview guidelines, and student's score report cards. The research took two months. Based on the results of the study, the mathematical literacy abilities of grade VIII students in solving hots questions are at level 4, namely: Level 4: Work effectively with models in concrete but complex situations that may involve restrictions on making assumptions, selecting and combining different representations, including on symbols, relating them to real situations, using their limited range of skills and arguing with some clear contextual views. So the student solves the HOTS problem correctly.
\end{abstract}

Keywords: Mathematical Literacy, HOTS

\section{INTRODUCTION}

Mathematics is a branch of science that is very important and inseparable in everyday life. Therefore mathematics education is one of the vital subjects and is taught at all education levels, from elementary school to tertiary education. [1] Mathematics is continuously developing in terms of material and its benefits for society. Mathematics education aims to help students develop their abilities, from the lowest to the highest abilities [2].

According to PISA 2015, Indonesia was 64th out of 65 participant countries, and TIMSS results showed that Indonesia ranks 45 th out of 50 TIMSS participants. PISA results in the study of mathematical literacy of Indonesian students have not yet reached the average PISA standard. Mathematical literacy in the PISA study consists of 6 levels; level 1 is a group of questions with a low scale, and level 6 is a group of questions with a high ranking. [3] PISA determines that the average international score is at level 3 or a score of 500, and Indonesia has not yet reached the global average score.
According to PISA results, Indonesian students have been able to occupy levels 1 and 2 of mathematical literacy, which means that Indonesian students have been able to answer routine math questions and have been able to use formulas to solve problems [4]. Mathematical literacy skills level 3 and 4 are a group of questions on a medium scale, and Indonesian students have not solved this level of mathematical literacy skills, especially for students who study mathematical HOTS questions. Some opinions say that HOTS is in the last three Bloom's Taxonomy levels, namely analysis, synthesis, and evaluation.

Another fact obtained is that the eighth-grader at SMPN 3 Tarakan still does not understand the types of mathematics HOTS questions, even though most of the National Examination questions have applied the HOTS type of questions. Students only complained about the difficulty in answering when they had to work on questions taken from the previous year's UN questions. Also, based on the results of interviews with mathematics teachers at the school, it was said that the mathematical literacy skills of students at SMPN 3 were also lacking. 
Mathematical literacy skills are needed in solving the types of HOTS (Higher Order Thinking Skills) Questions [5] as Bloom's Taxonomy which is famous for theory of thinking, expresses several levels of thinking, namely knowledge, understanding, application, analysis, synthesis, and evaluation. To train junior high school students' mathematical literacy skills, the best step is to give Higher Order Thinking Skills-based math questions because they will be trained in higher-order thinking processes with habituation. The purpose of HOTS-based questions is to measure higher-order thinking skills.

Based on the above background, the researcher is interested in carrying out the research entitled "Analysis of Mathematical Literacy Ability of Class VIII Students of SMPN 3 Tarakan in Resolving Higher Order Thinking Skills (HOTS) Questions".

[6] Mathematical literacy is the individual's capacity to formulate, use, and interpret mathematics in various contexts. It includes mathematical reasoning and mathematical concepts, procedures, facts, and tools to describe, explain, and predict phenomena. It helps individuals recognize the role mathematics plays in the world and make reasoned judgments and decisions that constructive, engaged, and reflective citizens need. Meanwhile, [7] mathematical literacy is defined as the ability of an individual to formulate, use and interpret mathematics in various contexts.

So from some expert opinions, it appears that mathematical literacy is never separated from three components: content, context, and competence. The mathematical literacy ability in this study is concluded as an individual ability to use the concept of procedures and facts to solve mathematical problems in various contexts correctly and accurately. [6] The criteria for the literacy level used are adjusted to the level developed by PISA (OECD, 2015), as shown below:

Table 1. Criteria of Literacy

\begin{tabular}{|c|c|c|c|}
\hline No & Level & & Criteria \\
\hline \multirow{3}{*}{1} & \multirow{3}{*}{6} & a. & $\begin{array}{l}\text { Conduct drafting, generalizing, } \\
\text { and using information based on } \\
\text { analysis and modeling in a } \\
\text { complex situation and can use } \\
\text { above-average knowledge. }\end{array}$ \\
\hline & & b. & $\begin{array}{l}\text { Link various sources of } \\
\text { information and representations, } \\
\text { and translate between them } \\
\text { flexibly. Students at this level } \\
\text { have high mathematical thinking } \\
\text { and reasoning abilities. }\end{array}$ \\
\hline & & c. & $\begin{array}{l}\text { Applying knowledge, mastery, } \\
\text { and relationships of mathematical } \\
\text { symbols and operations, } \\
\text { developing new strategies and } \\
\text { approaches for dealing with new } \\
\text { situations }\end{array}$ \\
\hline
\end{tabular}

\begin{tabular}{|c|c|c|c|}
\hline \multirow{3}{*}{2} & \multirow{3}{*}{5} & a. & 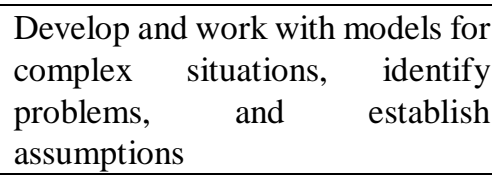 \\
\hline & & b. & $\begin{array}{l}\text { Select, compare, and evaluate } \\
\text { appropriate problem-solving } \\
\text { strategies related to complex } \\
\text { problems associated with the } \\
\text { model }\end{array}$ \\
\hline & & c. & $\begin{array}{l}\text { Work strategically by using a } \\
\text { broad range of thinking and } \\
\text { reasoning and appropriately } \\
\text { linking representations }\end{array}$ \\
\hline \multirow{3}{*}{3} & \multirow{3}{*}{4} & a. & $\begin{array}{l}\text { Work effectively with models in } \\
\text { concrete but complex situations } \\
\text { that may involve restrictions on } \\
\text { making assumptions. }\end{array}$ \\
\hline & & b. & $\begin{array}{l}\text { Selecting and combining different } \\
\text { representations, including } \\
\text { symbols, relating them to real } \\
\text { situations }\end{array}$ \\
\hline & & c. & $\begin{array}{l}\text { Using his limited range of skills } \\
\text { and arguing with several views in } \\
\text { clear context }\end{array}$ \\
\hline \multirow{3}{*}{4} & \multirow{3}{*}{3} & a. & $\begin{array}{l}\text { Carry out procedures clearly, } \\
\text { including procedures that require } \\
\text { consecutive decisions. }\end{array}$ \\
\hline & & b. & $\begin{array}{l}\text { Solve problems, and apply a } \\
\text { simple strategy }\end{array}$ \\
\hline & & c. & $\begin{array}{l}\text { Interpret and use representations } \\
\text { based on various sources of } \\
\text { information and state the reasons } \\
\text { why }\end{array}$ \\
\hline \multirow{3}{*}{5} & \multirow{3}{*}{2} & a. & $\begin{array}{l}\text { Interpreting and recognizing } \\
\text { situations in the context that } \\
\text { require immediate conclusions }\end{array}$ \\
\hline & & b. & $\begin{array}{l}\text { Sorting out relevant information } \\
\text { from a single source and using a } \\
\text { single presentation method }\end{array}$ \\
\hline & & c. & $\begin{array}{l}\text { Work on basic algorithms, use } \\
\text { formulas, carry out procedures or } \\
\text { agreements }\end{array}$ \\
\hline \multirow{3}{*}{6} & \multirow{3}{*}{1} & a. & $\begin{array}{l}\text { Answering questions in a familiar } \\
\text { context and all relevant } \\
\text { information provided with clear } \\
\text { questions }\end{array}$ \\
\hline & & b. & $\begin{array}{l}\text { Identify information, and carry out } \\
\text { common ways based on explicit } \\
\text { instructions. }\end{array}$ \\
\hline & & c. & $\begin{array}{l}\text { Show action following the } \\
\text { stimulation given. }\end{array}$ \\
\hline
\end{tabular}

An individual is said to be capable of mathematical literacy characterized by an excellent analytical process, can provide mathematical explanations and properly 
relate mathematical skills, and interpret mathematical problems in all contexts relating to all forms of mathematical models related to mathematical operations and opportunities and mathematical concepts.

[8] [9] HOTS questions are a situation-based assessment in everyday life, so that the problems with HOTS questions are contextual-based. The contextual problems referred to are problems faced by the world community today related to the environment, health, earth, and space and the use of science and technology in various aspects of life. This understanding also includes how students' skills to relate, interpret, apply and integrate knowledge in classroom learning to solve problems in an authentic context.

So it can be concluded that HOTS (Higher Order Thinking Skill) questions involve the following aspects: understanding, application, synthesis, analysis, or evaluation, not just remembering, restating, or processing.

\section{METHOD}

This type of research is descriptive with a qualitative approach. [10] [11] [12] Descriptive study is research directing to describe symptoms, facts, or incidents systematically and accurately regarding the characteristics of the research subject, in addition to understanding the phenomena experienced by the research subject, for example, behavior, perception, action, and others, holistically, and employing descriptions in the form of words and language by making use of various scientific methods.

This study seeks to describe students' literacy skills in solving HOTS questions. Thus the data obtained are in the form of written completion and interview results.

The research subject was a student of SMPN 3 Tarakan. The selection of research subjects was carried out by looking at their cognitive abilities. Students who have good communication skills will be selected. It is done because researchers need students who can provide or convey ideas or reasons to explore more deeply the research subject. The stages carried out by the researcher in determining the research subject in outline include:

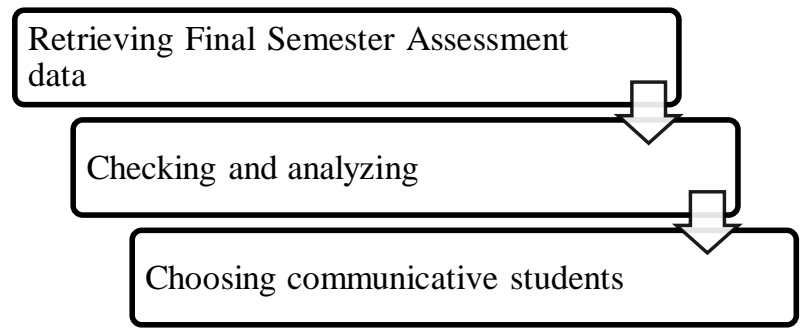

Figure 1 Stages Determining Subject

[13] [14] The main instrument was the researcher herself means the researcher is the determinant in filtering the data. Therefore, the researcher actively participated during the research process and the activities of research subjects related to data collection through the written test of HOTS and interviews.

The interview guide serves as a reference or guide for researchers so that the interview is directed. The interview guidelines in this study refer to indicators. Suppose the subject has difficulty answering the questions posed. In that case, a more straightforward question is given without changing the meaning of the problem so that the researcher can better understand the student's understanding. To not miss any information, the interview between the researcher and the research subject was recorded using an audio-visual instrument and then transcribed.

In data collection, the researcher gave HOTS written test to the research subject. After passing the test, the researcher interviewed the research subject's problems to find how the research subject solved the problem. This process produces data in the form of written and oral answers in the form of recordings. The recorded interviews will be transcribed in detail to produce interview transcripts and be combined with field notes and the results of observations by researchers during the interview.

In qualitative research, data analysis involves reviewing, sorting, and grouping data for a specific purpose. Data analysis starts from preparation. The data analysis technique was carried out through the following stages:

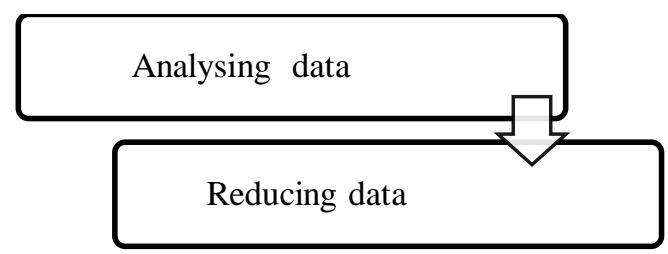

Figure 2 Stages of Technique Analysis

The reduced data was intended to select and focus the data that has been obtained in the field. The transcribed interview result and written test were analyzed as the following: 


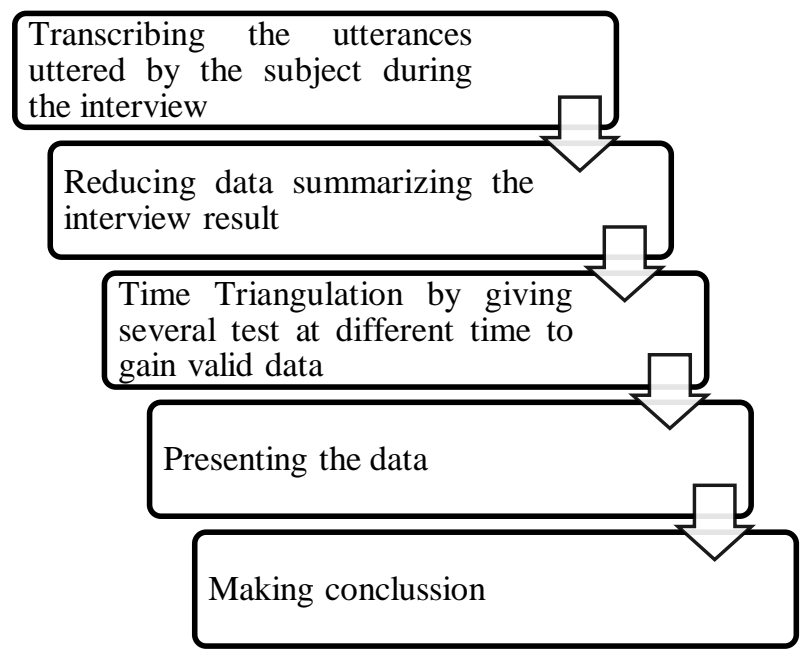

Figure 3 Stages of Analysing the Research Result

\section{RESULT AND DISCUSSION}

The supporting instrument for this research was HOTS-based Mathematical Questions. HOTS questions are questions whose solution requires thinking critically, logically, metacognitive, and thinking creatively, which are high-order thinking skills. The question instruments in this study were used to determine students' mathematical analysis skills. The question instrument consists of HOTS questions. Interview guidelines were made to conduct interviews so that no information was missed in the research.

The selection of research subjects was carried out based on the steps that have been determined in research methods. The Final Semester Score was analysed, namely, SMP Negeri 3 Tarakan students, class VIII-1, totalling 28 students based on the researcher's consultation with the class teacher. Selected students with code S01 are research subjects who have good cognitive abilities.

Based on the results of the HOTS test and subject 1 (S01) interview, the following data were obtained from the analysis of mathematical literacy skills. The HOTS questions given can be answered correctly. Researchers also conducted interviews with the subject. It is found that [15] the subject read the questions carefully before answering the given question and immediately write down the questions into math sentences. This stage is evident from the students' answers when writing is known. Work effectively with models in concrete but complex situations that may involve restrictions on making assumptions. It is continued to the next stage; [16] [17] the subject chooses the right strategy to solve problems related to complex problems related to the model. When selecting a strategy to solve the questions, Subject used a relatively short method to combine the SPLDV elimination method and substitution.
Subject selects and combines different representations, including symbols, relating them to real situations. The next stage is to state the reasons with several clear contextual views. The study results appears that the subject meets the 4th level in mathematical literacy skills. As for level 4, students can: a) work effectively with models in concrete but complex situations that may involve restrictions on making assumptions, b) Select and combine different representations, including symbols, relate them to real situations, c) Use multiple his limited skills and argues with several clear contextual views.

\section{CONCLUSIONS}

Based on the results of research and discussion, it can be concluded that the mathematical literacy skills of the VIII grade students of SMPN 3 Tarakan in solving HOTS questions are at the 4th level, namely:

a. Work effectively with models in concrete but complex situations that may involve restrictions on making assumptions.

b. Selecting and combining different representations, including symbols, relating them to real situations.

c. Using his limited range of skills and arguing with several clear contextual views

\section{AUTHOR'S CONTRIBUTIONS}

Setia Widia Rahayu was the compiler of the research proposal, prepared the instruments, collected data, analyzed the research data, and wrote it.

\section{ACKNOWLEDGMENTS}

The author's gratitude goes to the Rector of the Borneo University of Tarakan and LP2M, who have provided funding support for DIPA Borneo Tarakan University so that this research can be completed properly. This gratitude is to Dr. Suyadi, M.Ed as the Dean of the Teaching and Education Faculty, and Mr. Fendi Nurdianto as the Teacher of SMPN 3, who have been willing to be partners this research.

\section{REFERENCES}

[1] E. E. Rohaeti, "Analisis Pembelajaran Konsep Esensial Matematika Sekolah Menengah Melalui Pendekatan Kontekstual Socrates," Infinity Journal, vol. 1, no. 2, pp. 186-191, 2012.

[2] I. P. Sari, R. Purwasih and A. Nurjaman, "Analisis Hambatan Belajar Mahasiswa Pada 
Mata Kuliah Program Linear," vol. 6, no. 1, pp. 39-46, 2017.

[3] S. A. Widodo, " UNDERGRADUATE THESES (Koleksi Skripsi Sarjana)," 412 2015. [Online]. Available:

http://repository.unej.ac.id/handle/123456789/6 6471?show=full. [Accessed 17 January 2021].

[4] L. H. Jufri , "Jufri, L. H. (2015). Penerapan Double Loop Problem Solving Untuk Meningkatkan Kemampuan Literasi Matematis Level 3 pada Siswa Kelas VIII SMPN 27 Bandung," Letter of Mathematics Education, vol. 2, no. 1, pp. 52-62, 2015.

[5] M. Gershon, How to Use Bloom's Taxonomy in the Classroom The Complete Guide, Blairsville: Learning Sciences International, 2018.

[6] OECD, " PISA 2015: Draft Mathematics Framework," OECD Publishing, Paris, 2015.

[7] H. Setiawan, D. Dafik, S. Lestari and N. Diah, "Soal Matematika dalam PISA Kaitannya dengan Literasi Matematika Dan Keterampilan Berpikir Tingkat Tinggi," in Seminar Nasional Matematika Universitas Jember, Jember, 2014.

[8] K. S. Ramus, . P. K. Misra and T. Maguire, The Troika of Adult Learners, Lifelong Learning, and Mathematics: Learning from Research, Current Paradoxes, Tensions and Promotional Strategies, NY: New York: Springer, 2016.

[9] S. M. Brookhart, How to Assess Higher-order Thinking Skills in Your Classroom, Alexandria: ASCD, 2010.

[10] W. . N. Suter, Introduction to Educational Research: A Critical Thinking Approach, 2nd Edition ed., California: SAGE Publications,Inc, 2012.

[11] D. Ary, L. Jacobs, A. Razavieh and . C. Sorensen, Introduction to Research in Education, Boston: Cengage Learning, 2009.

[12] M. G. Lodico, D. T. Spaulding and K. H. Voegtle, Methods in Educational Research: From Theory to Practice, 2nd Edition ed., San Farnsisco: Jossey-Bass, 2010.

[13] R. K. Yin, Qualitative Research from Start to Finish, 1st Edition ed., NY; New York: The Guildford Press, 2011.
[14] J. Ritchie, J. Lewis, C. . M. Nicholls and . R. Ormston, Qualitative Research Practice: A Guide for Social Science Students and Researchers, California: SAGE Publication Ltd, 2013.

[15] S. Puspa, R. Riyadi and S. Subanti, "Profile of mathematical communication skills junior high school students in problem solving," in J. Phys.: Conf. Ser. 1157 032125, Bandung, 2018.

[16] D. B. Chin, . K. P. Blair, R. C. Wolf, . L. D. Conlin, M. Cutumisu, . J. Pfaffman and . D. L. Schwartz, "Educating and Measuring Choice: A Test of the Transfer of Design Thinking in Problem Solving and Learning," Journal of the Learning Sciences, vol. 28, no. 3, pp. 337-380, 2019.

[17] M. . S. F. Chong, M. Shahrill and H.-. C. Li, "The Integration of A Problem-Solving Framework for Brunei High School Mathematics Curriculum in Increasing Student's Affective Competency," Journal on Mathematics Education, vol. 10, no. 2, pp. 215-228, 2019. 